\title{
Az Európai Újraélesztési Társaság (ERC) 2021. évi gyermekújraélesztés ajánlásának összefoglaló bemutatása
}

\author{
Pandur Attila, Schiszler Bence, Tóth Balázs, \\ Pécsi Tudományegyetem Egészségtudományi Kar, Sürgősségi Ellátási és Egészségpedagógiai Intézet, Oxyológiai, \\ Sürgősségi Ellátási Tanszék, Pécsi Tudományegyetem Egészségtudományi Doktori Iskola
}

Bogár Bence, Jauch Melinda,

Pécsi Tudományegyetem Egészségtudományi Kar, Ápolás és Betegellátás Alapszak mentőtiszt szakirány

Prof. Dr. Betlehem József,

Pécsi Tudományegyetem Egészségtudományi Kar, Sürgősségi Ellátási és Egészségpedagógiai Intézet

Pandur Attila szakoktató

Kapcsolattartó szerző

Priskin Gábor, Dr. Radnai Balázs,

Pécsi Tudományegyetem Egészségtudományi Kar, Sürgősségi Ellátási és Egészségpedagógiai Intézet,

Oxyológiai, Sürgősségi Ellátási Tanszék

\section{Bevezetés:}

Jelen referátum az Európai Reszuszcitációs Társaság (ERC) és az International Liaison Committee on Resuscitation (ILCOR) által 2021-ben kiadott gyermekújraélesztés irányelveit foglalja össze. Terjedelmi okok miatt a referátum nem tartalmazza az egyes lépések teljes körű magyarázatát, a cél az új irányelvek rövid összefoglalása. Az ajánlás a csecsemőkori (4 hetes kortól), a kisgyermekkori (egy éves kortól) és gyermek (1-18 életév) ellátási specifikumait foglalja össze.

A csecsemőújraélesztéstől eltekintve a gyermekújraélesztés ritka. A kórházon kívüli keringésmegállásoknál a legtöbb esetben nem specifikus gyermekegység végzi az újraélesztést. Éppen ezért a cél, hogy az algoritmus egyszerü legyen, könnyen elsajátítható minden szakember számára. Meg kell jegyezni, hogy e témakörben kevés az evidencia szintű vizsgálati eredmény. A legfontosabb üzenet továbbra is a megelözés.

\section{Epidemiológia}

Az elérhető epidemiológiai adatok alapján elmondható, hogy a kórházon kívüli keringésmegállás ritka, de nagyon kedvezőtlen a prognózisa. Bár az elmúlt években javultak a túlélési mutatók, a 30 napos túlélés így is $5-10 \%$ világszerte. A sokkolandó ritmusok aránya alacsony: 4-8,5\%. A nem sokkolandó ritmusok esetén a fö ok továbbra is légzési eredetü probléma az esetek 40-50\%-ban, 10-40\%-ban pedig trauma. A kórházon belüli keringésmegállások (IHCA) esetén a túlélési adatok jobbak, 37-61\% közöttiek, ugyanakkor a neurológiai kimenetelre vonatkozó mutatók mindkét csoport esetén rosszak. (1)(2)(3) Összességében elmondható, hogy nincs globális, egységes adat a gyermekek keringésmegállásával kapcsolatban. Fontos lenne egy közös nemzetközi regiszter létrehozása, amely hosszútávon a gyermekek érdekeit szolgálhatná. (4)

\section{Változások a (pato)fiziológiai folyamatok értelmezésében, az új evidenciák tükrében}

A gyermekellátás során az első állapotfelmérés elengedhetetlen. Több különböző rendszer közül választhat az ellátó, melyek jól alkalmazhatók, mint például a gyermek állapotát felmérő háromszög (PAT). A guideline-ban nagyobb hangsúlyt kap a strukturált ABCDE algoritmus használata. A technikai fejlődésnek köszönhetően egyre nagyobb szerepet kapnak az 
ágy melletti laboratóriumi és képalkotó diagnosztikai eszközök. (5)(6)(7) Megfelelő számú és képzettségű teamek szükségesek a kritikus állapotú gyermekek sikeres ellátásához. A csapatoknak, a diagnosztikai eszközök mellett, klinikai döntéshozatalt támogató kockázat és állapotfelmérő score rendszerek alkalmazása is fontos a kritikus állapotú gyermekek korai felismerésére. (8) Az összeszokott teamek esetén is nélkülözhetetlen a folyamatos elméleti ismeretek és gyakorlati készségek fejlesztése, a rendszeres szervezett csapat feedback egy-egy ellátást követően. Ez képes a következő esetellátás során fennálló külső tényezők és belső stresszfaktorok csökkentésére. (9) Kritikus állapotú gyermekellátás során fontos az adekvát terápia alkalmazása. Gyógyszeralkalmazás során lehetőségünk van a Broselow szalag, vagy a szülő által mondott testsúly használatára, ugyanakkor az életkorból levezetett dozírozás is jól alkalmazható. Számos klinikai kutatás eredményei alapján hatékonyabb és pontosabb dozírozás végezhető a testhosszon alapuló testalkati korrekcióval végzett kalkulációval. (10)(11)(12) A gyógyszerek mellett a gyermekspecifikumok ismerete is fontos. A légútmenedzsment esetén a videolaryngoszkópia egyre nagyobb teret nyer a hagyományosan végzett endotracheális intubációval szemben, a sikeresebb első feltárás és kevesebb mellékhatása miatt. (13) Légzési elégtelen gyermekek ellátása során a ventiláció biztosítása, keringési elégtelenség esetén a folyadékpótlás és keringéstámogatás szerepe növekedett. (14) Szeptikus sokk gyanúja esetén három órán túl indított antibiotikum adás csökkenti a túlélés esélyét. (15) Kórházon kívüli keringésmegállások esetén a laikusoknak kulcsszerepe van a túlélési lánc első láncszemeként, hisz olyan erős a lánc, mint amilyen erősek az egyes láncszemek. $\mathrm{Az}$ okoseszközök fejlődése lehetővé teszi, hogy a keringésmegállás korai felismerése után, telefonon keresztül támogatott laikus CPR növelje a jó neurológiai kimenetelü túléléseket. (16)

\section{Gyermek alapszintü újraélesztés (PBLS)}

A guideline alkotók célja egy a felnőtt BLS algoritmussal minél egységesebb ajánlás kialakítása az egyszerüsítés érdekében. Gyermek BLS képzésen részt vett személyek számára javasolják a gyermek BLS algoritmus követését, míg ebben nem jártas személyek telefonon keresztül vezetett $B L S$ végzését.
Győződjünk meg róla, hogy biztonságos-e a helyszín, valamint az ellátó saját biztonságáról is gondoskodjuk, kiegészítve a potenciális COVID-19 ellátási specifikumokkal.

Vonjuk verbális és tactilis ingerekkel kontaktusba a gyermeket.

Kiáltsunk segítségért.

\section{BIZTONSÁGOS HELYSZÍN?}

Segitségért kiáltás!

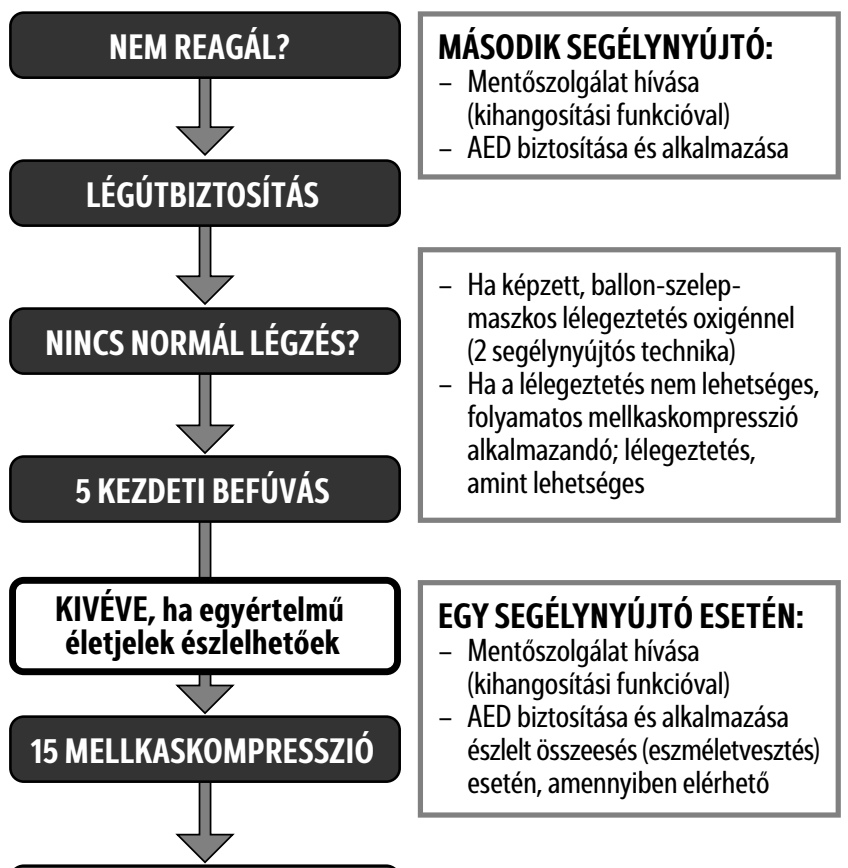

2 LÉLEGEZTETÉS, MAJD

15 KOMPRESSZIÓ:

2 LÉLEGEZTETÉS

1. ábra: A PBLS algoritmusa

Amennyiben a gyermek nem reagál, biztosítsunk átjárható légutat és vizsgáljuk 10 másodpercig a légzését. Terminális légzés vagy gasping esetén ne hezitáljunk, tekintsük nem légző gyermeknek. A légzést hármas észleléssel vizsgáljuk, amennyiben több segélynyújtó is jelen van, már légzésvizsgálat közben hívjuk a segélyhívót és hangosítsuk ki a telefont.

Amennyiben a gyermeknek nincs légzése, végezzünk 5 kezdeti befúvást. Sikertelen befúvás esetén próbáljuk újrapozícionálni a fejét, ha mellkasmozgást nem észlelünk tekintsünk a szájüregbe és távolítsuk el a légúti akadályt. Szakképzett személy ballon szelep maszk segítségével végezze a kezdeti 5 befúvást. Egy ellátó esetén az 5 
kezdeti befúvást követően hangosítsuk ki a telefonunkat. Amennyiben telefon nem érhető el, 1 perc folyamatos CPR után hagyjuk csak magára a gyermeket.

Az 5 kezdeti befúvást követően azonnal folytassuk 15 mellkaskompresszióval, ha nem látunk a keringésre utaló egyértelmű jeleket (köhögés, mozgás).

Mellkaskompresszió jellemzői nem változtak: továbbra is a cél a szünetek minimalizálása, a frekvencia 100-120/ perc, a mellkaskompresszió helye a sternum alsó harmada, a processus xyphoideus felett egy harántujjal, mélysége a mellkas antero-posterior átméröjének harmada, mellkas felengedése is biztosítandó továbbra is.

Csecsemők esetén a kompressziók során a „körülöleléses" technikát alkalmazzuk. Szuboptimális minőségű mellkaskompresszió érhető csak el a kétujjas módszerrel.

1 éves kor felett az egykezes, vagy kétkezes technika alkalmazandó.

Végezzük folyamatosan a 15:2 kompresszió:lélegeztetési köröket, minimalizáljuk a mellkaskompressziók közötti szünetet, a mellkaskompresszió hatékonysága érdekében gyakran cseréljük a segítségnyújtót. Amennyiben keringés jeleit észleljük, de a gyermek kontaktusba nem vonható, végezzünk lélegeztetést az életkornak megfelelő frekvenciával.

Azon elsősegélynyújtók számára, akik csak a felnőtt BLS-ben jártasak, gyermek újraélesztés esetén is a felnőtt algoritmus követendő. Laikusok esetén telefonon keresztül segített újraélesztés végzendő. Ha rendelkezésre áll félautomata defibrillátor, használjuk, lehetőség szerint 8 év alatt csökkentett energiaértékkel.

Traumás keringésmegállás esetén minimalizáljuk a mozgatást, végezzünk direkt nyomást külső vérzés esetén vagy használjunk tourniquetet kontrollálatlan vérzések esetén.

Stabil oldalfektetés gyermekek esetén is alkalmazható, kontraindikáció hiányában. Perceként vizsgáljuk újra a gyermek légzését.

$\mathrm{Az}$ idegentest okozta légúti elzáródás potenciálisan életveszélyes állapot, melynek korai felismerése elengedhetetlen annak érdekében, hogy megakadályozzuk a keringésmegállást. Légúti idegentest esetén eszméleténél lévő gyermeket biztassunk köhögésre. Amenynyiben a köhögés hatástalanná válik végezzünk 5 háti ütést, majd 5 hasi lökést eszméleténél lévő gyermeknél. Eszméletlenség esetén a gyermek BLS algoritmus szerint járjunk el.

\section{BIZTONSÁGOS HELYSZINN?}

Segítségért kiáltás!

\section{GYANÚ LÉGUTI ELZÁRÓDÁST OKOZÓ IDEGENTESTRE}

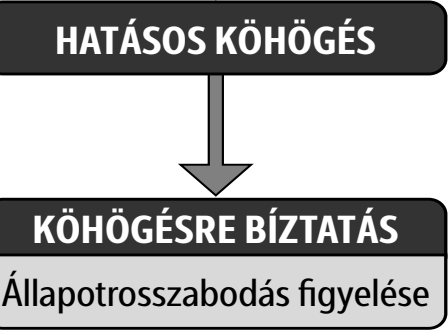

Állapotrosszabodás figyelése

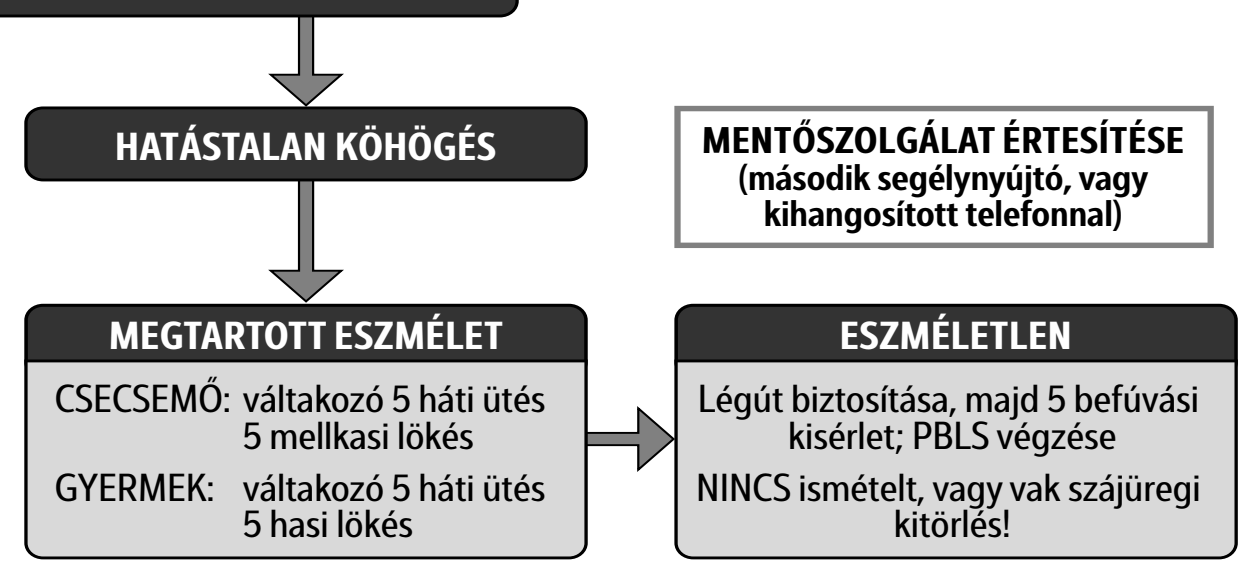

AMINT TÁVOZIK AZ IDEGENTEST, AZONNALI ORVOSI ELLÁTÁS! 


\section{Gyermek emelt szintủ újraélesztés (PALS)}

Amennyiben már folyik a BLS, folytassuk a megkezdett ellátást. Amint az emelt szintű újraélesztéshez szükséges eszközök, gyógyszerek és képzett személyzet rendelkezésre áll, el kell kezdeni az ALS-t. Mielőbb csatlakoztassuk a monitort annak érdekében, hogy elkülönítsük a sokkolandó (VF, pnVT) és nem sokkolandó (EMD, asystolia) ritmusokat.

Nem sokkolandó ritmusok esetén a legfontosabb teendő a minőségi mellkaskompresszió-lélegeztetés, valamint az adrenalin adása.

Mielőbb biztosítsunk intravénás vagy intraosszealis utat, és adjunk $10 \mu \mathrm{g} / \mathrm{ttkg}$ adrenalint. Ismételjük 3-5 percenként.

Sokkolandó ritmusok esetén a legfontosabb teendő a minőségi mellkaskompresszió-lélegeztetés, valamint a defibrilláció.

Amennyiben a defibrillátor elérhető, mielőbb le kell adni $4 \mathrm{~J} /$ tttkg energiaértékü sokkot. Használjunk öntapadó elektródákat a mellkaskompresszió szüneteltetésének minimalizálása érdekében (mely legfeljebb $5 \mathrm{sec}$ ). Harmadik sokkot követően adjunk $10 \mu \mathrm{g} / \mathrm{ttkg}$ adrenalint, valamint $5 \mathrm{mg} / \mathrm{ttkg}$ amiodaront. Ötödik sokkot követően ismételjük az adrenalint és az amiodaront az előbb ismertetett dózisokban. Ezt követően 3-5 percenként ismételjük az adrenalint. Lehetőség szerint 2 percenként cseréljük a mellkaskompressziót végző ellátót.

\section{Defibrilláció}

Továbbra is $4 \mathrm{~J} / \mathrm{ttkg}$ energiaértékek válasszunk. Refrakter VF, pnVT esetén, amennyiben legalább öt sokk leadása megtörtént, maximalizált $8 \mathrm{~J} / \mathrm{ttkg}$ alkalmazható. Preferáljuk az öntapadó elektródákat, anterolateralis vagy antero-posterior helyzetben.

\section{Lélegeztetés}

Újraélesztés közben alkalmazzunk ballon-szelepmaszkos (BSZM) lélegeztetést, lehetőség szerint 100\% oxigénkoncentrációval. Kerüljük a hyperventilációt, korai fázisban kezdjük el az $\mathrm{EtCO}_{2}$ monitorozást, amely segít a helyes tubuspozíció megítélésében, a spontán keringés visszatérését jelezheti, valamint döntéstámogató szerepe van az újraélesztés abbahagyásában. Amennyiben a BSZM nem hatásos, használjunk szupraglottikus eszközöket vagy endotracheális intubációt. Figyeljünk az életkorfüggő lélegeztetési frekvenciára, melyek:

\begin{tabular}{|c|c|c|c|}
\hline Csecsemő & $\begin{array}{c}1 \text { éves kor } \\
\text { felett }\end{array}$ & $\begin{array}{c}\mathbf{8} \text { éves kor } \\
\text { felett }\end{array}$ & $\begin{array}{c}10 \text { éves kor } \\
\text { felett }\end{array}$ \\
\hline 25/perc & $20 /$ perc & $15 /$ perc & $12 /$ perc \\
\hline
\end{tabular}

A spontán keringés visszatérése esetén (ROSC) célzott oxigénterápiát alkalmazzunk, az oxigénszaturáció 94-98\% közötti értékének elérése céljából. Végezzünk emelt szintű légútbiztosítást, amennyiben nem történt az újraélesztés közben.

\section{POCUS/POCT}

Gyakorlott ellátók a reverzibilis okok (4H-4T) azonosítására alkalmazhatnak ágy melletti képalkotó (ultrahang) és labordiagnosztikát (laktát, glükóz), amennyiben a minőségi CPR-t nem befolyásolja.

\section{TCA}

Gyermek traumás keringésmegállása (TCA) esetén a felnőtt TCA algoritmus szerint járjunk el a reverzibilis okok mielőbbi beazonosításával, kezelésével, thoracostomia elvégzésével megfelelő indikációk esetén, külső vérzések csillapításával.

\section{Hypothermia}

Hypothermia esetén a speciális körülmények fejezetben látható algoritmus szerint járjunk el.

\section{ECLS-Külső eszközzel támogatott újraélesztés}

Helyi protokolloknak megfelelően mérlegelendő az újraélesztés korai fázisában kórházon belül, illetve kórházon kívül megfelelő indikációval ECLS alkalmazása.

\section{Post-ROSC}

A spontán keringés visszatérése esetén számos tényező befolyásolja a gyermekek hosszútávú túlélését. Ezt segíthetjük a hypotenzió elkerülésével, életkorfüggő lélegeztetéssel, elkerülve a hypo-hyperkapniát, valamint a cél szaturációs érték biztosításával 94-98\%. Kerüljük el a hypo-hyperthermiát, valamint a hypo-hyperglycaemiát. 
BIZTONSÁGOS HELYSZIN?

Segítségért kiáltás!

KERINGÉSMEGÁLLÁS ÉSZLELHETŐ?

(Hypoxia vagy ischaemia talaján kialakult bradycardiát beleértve)

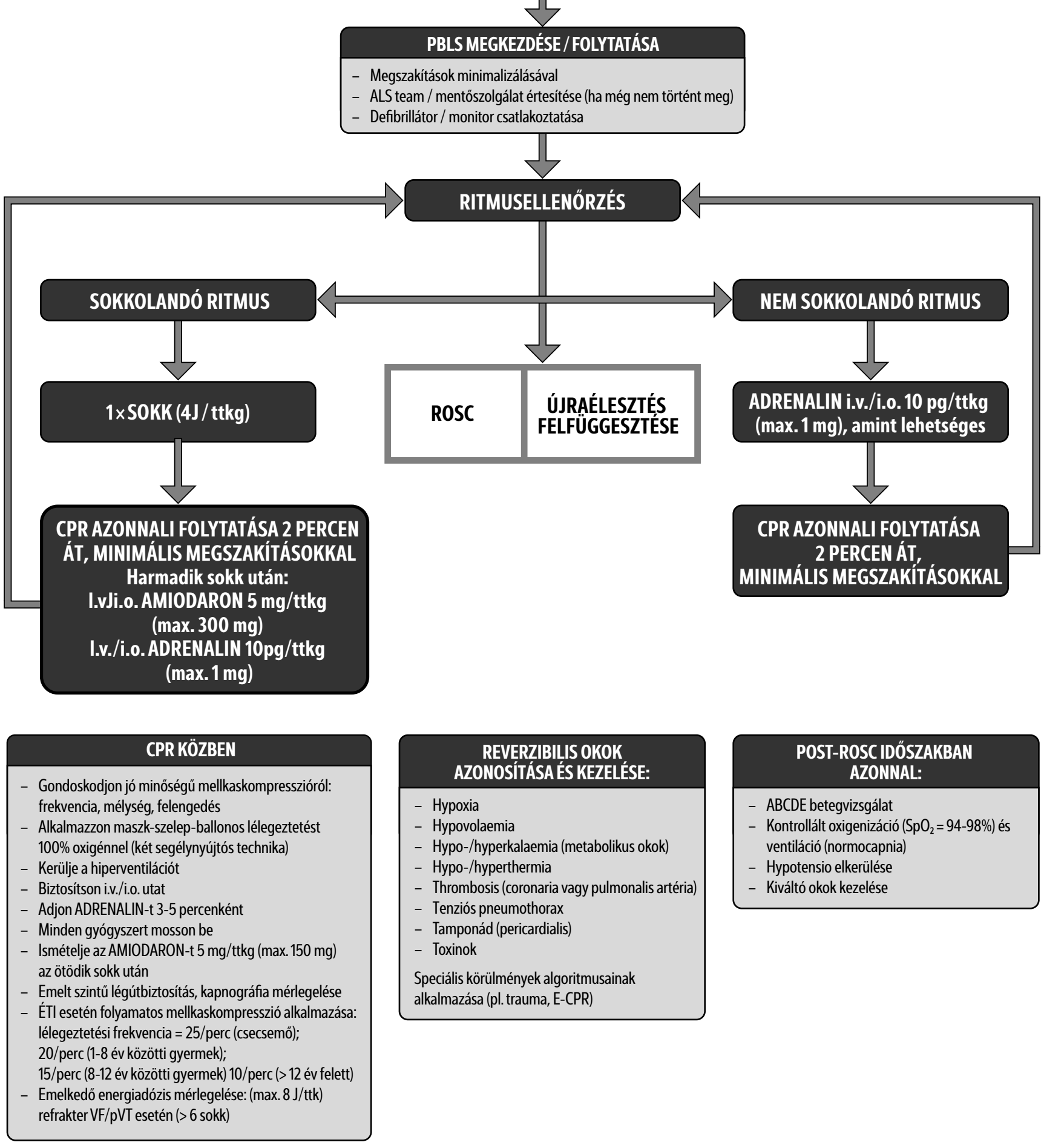

3. ábra: A PALS algoritmusa 


\section{Gyermekellátást igénylő kórfolyamatok specifikumai}

A következő táblázatban foglaltuk össze a guidelineban megjelenő gyermekellátást igénylő kórfolyamatok jellemzőit és ellátásukat. Fontos hangsúlyozni, hogy az
ABCDE szerinti megközelítés javasolt a gyermekellátás során is.

\begin{tabular}{|c|c|c|c|}
\hline \multirow[t]{2}{*}{$\Lambda$} & $\begin{array}{l}\text { Status } \\
\text { asthmaticus }\end{array}$ & $\begin{array}{l}\text { Klinikai jelek és anamnesztikus } \\
\text { adatok alapján értékeljük a gyermek } \\
\text { állapotát. } \mathrm{Sp}_{2} \text { monitorozás, } \\
\text { vérgázanalízis, félig üló helyzet } \\
\text { biztositása, } 94-98 \% \text { célszaturációs } \\
\text { érték, antibiotikum és adrenalin } \\
\text { rutinszerú adása nem javasolt. } \\
\text { Non-invazív lélegeztetés, amennyiben } \\
\text { elérhető alkalmazható }\end{array}$ & $\begin{array}{l}\text { Salbutamol: } 2-10 \text { exp. } \\
\text { Berodual inh: } 20-40 \mathrm{csepp} \\
\text { Kortikoszteroid: } 1-2 \mathrm{mg} / \mathrm{ttkg} \\
\text { Magnézium-szulfát: } \\
50 \mathrm{mg} / \mathrm{ttkg} 20 \text { perc alatt iv. }\end{array}$ \\
\hline & Anaphylaxia & $\begin{array}{l}\text { Hirtelen kezdetű nehézlégzés, } \\
\text { bőrkiütés, stridor, hypotenzió, } \\
\text { syncope, collapsus }\end{array}$ & $\begin{array}{l}\text { Adrenalin: } 0,01 \mathrm{mg} / \mathrm{ttkg} \text { i.m. } 5 \text {-10 percenként ismételhető } \\
\text { Antihisztamin } \\
\text { Metilprednisolon } 1-2 \mathrm{mg} / \mathrm{ttkg}\end{array}$ \\
\hline \multirow{4}{*}{ ( } & $\begin{array}{l}\text { Keringési } \\
\text { elégtelenség }\end{array}$ & $\begin{array}{l}\text { Klinikai jelek értékelése, a } \\
\text { perriarreszt állapot elkerülése }\end{array}$ & $\begin{array}{l}\text { Folyadékterápia: } 10 \mathrm{ml} / \mathrm{ttkg} \text { (max } 40-60 \mathrm{ml} / \mathrm{ttkg} \text { ) } \\
\text { Tranexámsav: } 15-20 \mathrm{mg} / \mathrm{ttkg} \text { (max. } 1 \mathrm{~g}) 2 \mathrm{mg} / \mathrm{ttkg} / \mathrm{h} \\
8 \text { óra alatt, vagy ameddig a vérzés nem áll el. } \\
\text { Noradrenalin/adrenalin első vonalbeli szer } \\
\text { keringéstámogatásra, alternatíva dopamin. }\end{array}$ \\
\hline & $\begin{array}{l}\text { Szepszis/ } \\
\text { szeptikus sokk }\end{array}$ & $\begin{array}{l}\text { Lehetőség szerint hemokultúra } \\
\text { mintavétel az antibiotikum terápia } \\
\text { elkezdése előtt. }\end{array}$ & $\begin{array}{l}\text { Folyadékreszuszcitáció és keringéstámogatás, } \\
\text { széles spektrumú antibiotikum adása }\end{array}$ \\
\hline & $\begin{array}{l}\text { Instabil } \\
\text { bradycardia }\end{array}$ & részletesen Isd algoritmus. & $\begin{array}{l}\text { Atropin: } 20 \mu \mathrm{g} / \mathrm{ttkg} \text { (max: 0,5 mg/dózis) sz.e. } \\
\text { pacemaker terápia }\end{array}$ \\
\hline & Tachycardia & részletesen Isd algoritmus. & $\begin{array}{l}\text { Stabil gyermek esetén: adenozin: 0,1-0,2 mg/ttkg (max } 6 \\
\text { mg) ismétlés } 0,3 \mathrm{mg} / \mathrm{ttkg} \text { (max: } 12-18 \mathrm{mg} \text { ) } \\
\text { Tdp esetén magnézium: } 50 \mathrm{mg} / \mathrm{ttkg} \text { Instabil gyermek } \\
\text { esetén: Szinkron sokk: } 1 \mathrm{~J} / \mathrm{ttkg} \text { (max: } 4 \mathrm{~J} / \mathrm{ttkg} \text { ) }\end{array}$ \\
\hline & $\begin{array}{l}\text { Status } \\
\text { epilepticus }\end{array}$ & $\begin{array}{l}\text { egyéb okok kizárása: } \\
\text { hypogylcaemia, elektrolit eltérések, } \\
\text { mérgezések, gyulladásos folyamatok, } \\
\text { légúti obstrukció, sokk, hypoxia }\end{array}$ & $\begin{array}{l}\text { IM midazolam 0,2 mg/ttkg (max } 10 \mathrm{mg} \text { ) intranazálisan/ } \\
\text { buccálisan: 0,3 mg/ttkg; IV } 0.15 \mathrm{mg} / \mathrm{kg} \text { (max } 7.5 \mathrm{mg} \text { ) } \\
\text { IV lorazepam 0,1 mg/kg (max. } 4 \mathrm{mg} \text { ) } \\
\text { IV diazepam 0,20-25 mg/kg (max } 10 \mathrm{mg}) / \text { rectálisan } \\
0.5 \mathrm{mg} / \mathrm{kg} \text { (max. } 20 \mathrm{mg}) 5 \text { percenként ismételhető, } \\
20 \text { percet meghaladó konvulzió esetén: levetiracetam: } \\
40-60 \mathrm{mg} / \mathrm{ttkg} \text { iv. fenitoin: } 20 \mathrm{mg} / \mathrm{ttkg} \text { iv. (max. } 1,5 \mathrm{~g} 20 \\
\text { perc alatt), fenobarbitál: } 20 \mathrm{mg} / \mathrm{ttkg} 20 \text { perc alatt }\end{array}$ \\
\hline D & Hypoglycaemia & $\begin{array}{l}\text { klinikai jelek értékelése glükózoldat } \\
\text { adagolása esetén } 10 \text { percenként } \\
\text { kontrolláljuk a vércukorszintet }\end{array}$ & $\begin{array}{l}2,8 \mathrm{mmol} / \mathrm{l} \text { alatti vércukorszint esetén: glükóz infúzió: } \\
0,3 \mathrm{mg} / \mathrm{ttkg} \text { iv. } 10 \% \text { (100 mg/ml } 3 \mathrm{ml} / \mathrm{ttkg} \text { ) vagy } 20 \% \text {-ból } \\
1,5 \mathrm{ml} / \mathrm{ttkg} \text { Glükózoldat hiányában glükagen } 0,03 \mathrm{mg} / \mathrm{ttkg} \\
\text { im. vagy sc. } 1 \mathrm{mg}>25 \mathrm{~kg}, 0,5 \mathrm{mg}<25 \mathrm{~kg}, 2,8 \mathrm{mmol} / \mathrm{l} \\
\text { alatti vércukorszint esetén: glükóz infúzió: } 0,3 \mathrm{mg} / \mathrm{ttkg} \text { iv. } \\
10 \% \text { (100 mg/ml } 3 \mathrm{ml} / \mathrm{ttkg} \text { ) vagy } 20 \% \text {-ból } 1,5 \mathrm{ml} / \mathrm{ttkg} \\
\text { Glükózoldat hiányában glükagen } 0,03 \mathrm{mg} / \mathrm{ttkg} \mathrm{im} \text {. } \\
\text { vagy sc. } 1 \mathrm{mg}>25 \mathrm{~kg}, 0,5 \mathrm{mg}<25 \mathrm{~kg} \text {, }\end{array}$ \\
\hline & Hyperthermia & ABCDE ellátási algoritmus & Hútés \\
\hline
\end{tabular}




\begin{tabular}{|l|l|l|}
\hline Hypokalaemia & $\begin{array}{l}\text { Perriarrest állapotban kezeljük, súlyos } \\
\text { hypokalémiában. }\end{array}$ & $\begin{array}{l}<2,5 \mathrm{mmol} / \mathrm{l} 1 \mathrm{mmol} / \mathrm{l}(\mathrm{max}: 30 \mathrm{mmol}) \text { iv. bolus. } \\
\text { Adjunk mellé } 30-50 \mathrm{mg} / \text { ttkg magnéziumot. }\end{array}$ \\
\hline \multirow{3}{*}{ Hyperkalaemia } & $\begin{array}{l}\text { értékeljük a rizikótényezőket, EKG } \\
\text { elváltozásokat, }\end{array}$ & $\begin{array}{l}\text { Ca-glükonát: } 10 \% 0,5 \mathrm{ml} / \mathrm{ttkg} \text { max. } \\
20 \mathrm{ml} 30-60 \mathrm{perc} \text { alatt }\end{array}$ \\
& & $\begin{array}{l}\text { Glükóz-inzulin: } 25 \mathrm{ml} \text { glüköz 20\%, 0,1 NE/ttkg inzulin } \\
\text { Bikarbonát: } 1 \mathrm{mmol} / \mathrm{ttkg} \text { iv. }\end{array}$ \\
\hline
\end{tabular}

\section{Mi változott/mi került a fó fókuszba a korábbi ERC2015 ajánláshoz képest?}

- A gyermekújraélesztési algoritmus kiterjed minden 0-18 év közötti gyermekre, kivétel az újszülöttek, ők külön guideline szerint kezelendők. Aki felnőttnek néz ki, azt felnőtt algoritmus szerint is kezelhető.

- Konzervatív oxigénterápia titrálása javasolt a célszaturációs (94-98\%) érték eléréséig. Légzésikeringés elégtelen gyermekek esetén mielőbbi magas áramlású oxigénadás javasolt.

- Keringési elégtelenség esetén adjunk mielőbb $10 \mathrm{ml} / \mathrm{ttkg}$ bólus folyadékot, amely ismételhető, ugyanakkor minden bólus után értékeljük újra a gyermek állapotát. A túltöltést kerüljük el. Hemorrhágiás sokk állapotokban minimalizáljuk a krisztalloid oldatokat, amint elérhető adjunk vérkészítményt.

- Minden olyan személy, aki gyermek BLS képzésen részt vett, alkalmazza a specifikus gyermek BLS irányelveket az alapszintűvel szemben.

\section{Irodalomjegyzék}

1. Nehme Z, Namachivayam S, Forrest A, Butt W, Bernard S, Smith K. Trends in the incidence and outcome of paediatric out-of-hospital cardiac arrest: a 17-year observational study. Resuscitation 2018;128:43 _50,

2. Phillips RS, Scott B, Carter SJ, et al. Systematic review and metaanalysis of outcomes after cardiopulmonary arrest in childhood. PLOS ONE 2015;10:e0130327

3. Gerein RB, Osmond MH, Stiell IG, Nesbitt LP, Burns $S$. What are the etiology and epidemiology of out-ofhospital pediatric cardiopulmonary arrest in Ontario, Canada? Acad Emerg Med 2006;13:653_8

4. Booth A, Moylan A, Hodgson J, et al. Resuscitation registers: how many active registers are there and how many collect data on paediatric cardiac arrests? Resuscitation 2018;129:70_5

5. Bortcosh W, Shaahinfar A, Sojar S, Klig JE. New directions in point-of-care ultrasound at the crossroads
- Gyermekújraélesztést végző képzett szakember az 5 kezdeti befúvást követően egyből kezdjen mellkaskompressziót, ha keringés jeleit nem észleli. Egy ellátó esetén mielőbbi telefonon keresztül vezetett újraélesztés javasolt. Amennyiben telefon nincs kéznél javasolt egy perc CPR végzése és ezt követően megszakítani az újraélesztést a telefon elérhetőségéig.

- Képzett szakember esetén javasolt a kétujjas technika alkalmazása a mellkaskompressziók során.

- Gyermek ALS esetén fontos a mielőbbi reverzibilis okok keresése és korrigálása.

- Négykezes ballon-szelep-maszkos lélegeztetés javasolt első lépésként gyermekújraélesztésben, minden kompetenciaszinten. Amennyiben emelt szintű légútbiztosítás megtörtént életkorfüggő lélegeztetési frekvencia alkalmazandó.

of paediatric emergency and critical care. Curr Opin Pediatr 2018;30:350_8

6. Holmes JF, Gladman A, Chang CH. Performance of abdominal ultrasonography in pediatric blunt trauma patients: a meta-analysis. J Pediatr Surg 2007;42: 1588 _94,

7. Scott HF, Brou L, Deakyne SJ, Kempe A, Fairclough DL, Bajaj L. Association between early lactate levels and 30-day mortality in clinically suspected sepsis in children. JAMA Pediatr 2017;171:249_55

8. Joffe AR, Anton NR, Burkholder SC. Reduction in hospital mortality over time in a hospital without a pediatric medical emergency team: limitations of before-and-after study designs. Arch Pediatr Adolesc Med 2011;165:419_23, 
9. Riskin A, Bamberger P, Erez A, et al. Expressions of gratitude and medical team performance. Pediatrics 2019143:,

10. Wells M, Goldstein LN, Bentley A. The accuracy of emergency weight estimation systems in children ${ }_{-}$a systematic review and meta-analysis. Int J Emerg Med 2017;10:29,

11. Young KD, Korotzer NC. Weight estimation methods in children: a systematic review. Ann Emerg Med 201668:,

12. Matson KL, Horton ER, Capino AC. Advocacy committee for the pediatric pharmacy advocacy g. medication dosage in overweight and obese children. J Pediatr Pharmacol Ther 2017;22:81

13. Kaji AH, Shover C, Lee J, et al. Video versus direct and augmented direct laryngoscopy in pediatric tracheal intubations. Acad Emerg Med 2020;27:394_402,
14. Balamuth F, Kittick M, McBride P, et al. Pragmatic pediatric trial of balanced versus normal saline fluid in sepsis: the PRoMPT BOLUS randomized controlled trial pilot feasibility study. Acad Emerg Med 2019;26:1346_56

15. Barboza CL, Valete CO, da Silva AR. Bundle adherence of intravenous antibiotic fluid resuscitation and vasopressor in children with severe sepsis or septic shock. Indian J Crit Care Med 2020;24:128_32

16. Olasveengen TM, Mancini ME, Perkins GD, et al. Adult basic life support: international consensus on cardiopulmonary resuscitation and emergency cardiovascular care science with treatment recommendations. Resuscitation 2020;156:A35_79 